\title{
Pengaruh Karakteristik Individu dan Faktor Ekstrinsik terhadap Kinerja Bidan
}

\section{The Influence of Individual Characteristics and Extrinsic Factors toward the Performance of Midwives}

\author{
Herna Linda $^{1)}$, Zulfendri Zulfendri ${ }^{2)}$, Juanita Juanita ${ }^{3)}$ \\ ${ }^{1)}$ Program Studi Magister Kesehatan Masyarakat, Universitas Sumatera Utara, Kota Medan \\ ${ }^{2,3)}$ Direktorat Pasca Sarjana Ilmu Kesehatan Masyarakat, Universitas Sumatera Utara, Kota Medan \\ e-mail korespondensi: lindaherna607@gmail.com
}

\begin{tabular}{|l|}
\hline Info Artikel \\
\hline Riwayat Artikel : \\
Diterima: 22 April 2021 \\
Disetujui: 30 Juli 2021 \\
Dipublikasikan: Juli 2021 \\
\hline Nomor DOI \\
10.33059/jseb.v12i2.3467 \\
Cara Mensitasi : \\
Linda, H., Zulfendri, Z., \& \\
Juanita, J. (2021). Pengaruh \\
karakteristik individu dan \\
faktor ekstrinsik terhadap \\
kinerja bidan. Jurnal Samudra \\
Ekonomi dan Bisnis, 12(2), \\
271-285. doi: 10.33059/jseb. \\
v12i2.3467.
\end{tabular}

v12i2.3467.

Abstrak

Kinerja bidan sebagai bagian dari sumber daya manusia yang dimiliki rumah sakit akan mempengaruhi kinerja institusi jasa kesehatan yang bersangkutan secara keseluruhan. Tujuan penelitian ini adalah untuk menganalisis pengaruh dari karakteristik individu (meliputi umur, masa kerja, status kepegawaian, keterampilan, dan motivasi) serta faktor ekstrinsik (meliputi imbalan, beban kerja, supervisi, dan pelatihan) terhadap kinerja bidan. Penelitian survey eksplanatori ini menggunakan seluruh bidan yang bertugas di ruang kebidanan rawat inap RSUD Langsa yang berjumlah 47 orang sebagai responden. Data dikumpulkan melalui kuesioner dan dianalisis dengan metode regresi logistik. Hasil penelitian menunjukkan bahwa status kepegawaian, keterampilan dan motivasi dari karakteristik individu serta supervisi dan pelatihan dari faktor ekstrinsik yang berpengaruh signifikan terhadap kinerja bidan. Lebih jauh, motivasi diidentifikasi sebagai variabel yang dominan mempengaruhi kinerja bidan.

Kata Kunci: Karakteristik Individu, Faktor Ekstrinsik, Kinerja Bidan.

\begin{tabular}{|c|c|}
\hline & Abstract \\
\hline & $\begin{array}{l}\text { The performance of the midwife as part of the human resources owned by the } \\
\text { hospital will affect the performance of the health service institution concerned } \\
\text { as a whole. The purpose of this study was to analyze the effect of individual } \\
\text { characteristics (including age vears of service emplovment status skills and }\end{array}$ \\
\hline $\begin{array}{l}\text { ulfendri, Z., \& } \\
\text { 021). Pengaruh } \\
\text { individu dan } \\
\text { nsik terhadap } \\
\text { 1. Jurnal Samudra }\end{array}$ & $\begin{array}{l}\text { motivation) and extrinsic factors (including rewards, workload, supervision, } \\
\text { and training) on the performance of midwives. This explanatory survey } \\
\text { research used all of the midwives who served in the inpatient obstetrics room at } \\
\text { Langsa Hospital, amounting to } 47 \text { people as respondents. Data were collected } \\
\text { through questionnaires and analyzed by logistic regression method. The results } \\
\text { showed that employment status, skills and motivation from individual } \\
\text { characteristics as well as supervision and training from extrinsic factors had a } \\
\text { significant effect on the performance of midwives. Furthermore, motivation was } \\
\text { identified as the dominant variable influencing the performance of midwives. }\end{array}$ \\
\hline
\end{tabular}

Keywords: Individual Characteristics, Extrinsic Factors, Midwife Performance. 


\section{PENDAHULUAN}

Persaingan antar perusahaan di era globalisasi semakin tajam, sehingga sumber daya manusia (SDM) dituntut untuk terus menerus mampu mengembangkan diri sendiri secara proaktif. SDM harus menjadi manusiamanusia pembelajar, yaitu pribadi-pribadi yang mau belajar dan bekerja keras dengan penuh semangat, sehingga potensi insaninya berkembang maksimal. Satu hal yang makin disadari pada dasa warsa ini adalah sumber daya manusia merupakan aset organisasi yang paling tinggi dibanding dengan sumber daya lainnya (Azwar, 2014; Buil et al., 2018; Purwanto et al., 2020). Bidan sebagai salah satu sumber daya manusia yang dimiliki oleh rumah sakit yang harus dikelola dengan tepat dalam proses menghasilkan jasa medis dan merupakan salah satu bagian yang paling penting dan tanggung jawab yang paling menantang dalam usaha kesehatan. Apalagi seiring kemajuan teknologi dan dinamika masyarakat, tuntutan kebutuhan masyarakat akan peningkatan pelayanan kesehatan ibu dan anak merupakan suatu tantangan yang cukup berat.

Berdasarkan informasi yang diperoleh dari kepala ruangan kebidanan di RSUD Kota Langsa diperoleh fenomena kemampuan dan pengalaman sebagai bidan masih belum maksimal dimana keterampilan dalam memberikan asuhan kebidanan masih terbatas pada keterampilan bersifat esensial dasar namun kurang memiliki kompetensi berbasis emergensi komprehensif, sementara berdasarkan data yang diperoleh bahwa 68,7\% kasus yang dirujuk ke rumah sakit adalah kasus yang memerlukan penanganan komprehensif. Selain itu, terindikasi pengalaman yang diperoleh lebih berasal dari pengalaman selama bekerja di rumah sakit, namun hanya sedikit pengalaman yang sesuai dengan kompetensi bidan, sehingga terlihat bahwa bidan yang memberikan asuhan kebidanan mayoritas adalah yang telah lama bekerja dan yang berusia rata-rata diatas 35 tahun.

Dalam menghadapi perkembangan yang kompetitif dan terglobalisasi, perusahaan membutuhkan karyawan yang berprestasi tinggi; karenanya perlu dilakukan penilaian yang menggambarkan kinerja karyawan (Rivai et al., 2012; Andayani \& Tirtayasa, 2019). Kinerja SDM adalah hasil atau tingkat keberhasilan seseorang secara keseluruhan selama periode tertentu dalam melaksanakan tugas dibandingkan berbagai kemungkinan, seperti standar hasil kerja, target, sasaran/ kriteria yang telah ditentukan terlebih dahulu dan telah disepakati bersama (Mulyasari, 2018; Murti \& Srimulyani, 2013; Diamantidis \& Chatzoglou, 2019). Kinerja merupakan konstruksi multidimensi yang mencakup sejumlah faktor yang mempengaruhinya (Mangkuprawira, 2012; Ardiansyah \& Sulistiyowati, 2018). Artikel ini berfokus pada karakteristik individu yang meliputi umur, masa kerja, status kepegawaian, keterampilan, dan motivasi, serta faktor ekstrinsik yang meliputi imbalan, beban kerja, supervisi, dan pelatihan.

Beberapa hal yang telah disebutkan menjadi alasan meneliti fenomena tentang pengaruh dari karakteristik individu serta faktor ekstrinsik terhadap kinerja bidan. Obyek penelitian pada Rumah Sakit Umum Daerah Kota Langsa, khususnya di ruang kebidanan rawat inap.

\section{Kinerja Bidan}

Sasaran utama manajemen sumberdaya manusia adalah menciptakan sistem pemberdayaan personil yang dapat menampilkan kinerja produktif. Kinerja berasal dari kata job performance atau actual performance yang berarti prestasi kerja prestasi sesungguhnya yang dicapai seseorang. Menurut pendekatan perilaku dalam manajemen, kinerja adalah kuantitas ataupun kualitas sesuatu yang 
dihasilkan atau jasa yang diberikan seseorang yang melakukan pekerjaan berdasarkan standar yang ditetapkan (Luthans et al., 2015; Dessler, 2016).

Kinerja juga adalah tingkat keberhasilan seseorang secara keseluruhan selama periode tertentu dalam melaksanakan tugas baik secara kuantitas maupun kualitas yang dicapai oleh seseorang dalam melaksanakan tugas sesuai tanggung jawab yang diberikan seperti standar hasil kerja, target atau sasaran atau kriteria yang telah ditentukan yang disepakati bersama (Rivai et al., 2015; Sutrisno, 2015). Dengan demikian, manajemen kinerja adalah keseluruhan kegiatan yang dilakukan untuk meningkatkan kinerja perusahaan ataupun organisasi, termasuk kinerja masing-masing individu dan kelompok kerja di perusahaan.

Proses penilaian prestasi ditujukan untuk memahami prestasi kerja seseorang. Penilaian kinerja perlu memiliki standar kinerja serta ukuran kinerja. Sistem penilaian memerlukan standar kinerja yang mencerminkan seberapa jauh keberhasilan sebuah pekerjaan telah dicapai (Sutrisno, 2015; Yuniarsih, 2013; Luthans et al., 2015). Agar efektif, standar perlu berhubungan dengan hasil yang diinginkan dari tiap pekerjaan. Hal tersebut dapat diuraikan dari analisis pekerjaan dengan menganalisis hubungannya dengan kinerja karyawan saat sekarang.

Bidan sebagai suatu profesi disiapkan melalui pendidikan formal agar lulusannya dapat melaksanakan/mengerjakan pekerjaan yang menjadi tanggung jawabnya secara profesional. Keberadaan bidan di Indonesia sangat diperlukan untuk meningkatkan derajat kesejahteraan ibu dan janinnya, dengan wilayah pelayanan berada di mana-mana dan kapan saja selama ada proses reproduksi manusia (Batbuall, 2019; Suryani et al., 2020). Bidan dalam melaksanakan peran, fungsi dan tugasnya didasarkan kepada kompetensi dan kewenangan yang diberikan, yang diatur melalui Peraturan Menteri Kesehatan (Permenkes) No. 900/Menkes/SK/ VIII/2002 dimana wewenang seorang bidan mencakup: (1) pelayanan kebidanan yang meliputi pelayanan kesehatan ibu dan anak; (2) pelayanan Keluarga Berencana; serta, (3) pelayanan kesehatan masyarakat.

Nilai kinerja bidan yang dianalisis pada artikel ini berpedoman dari penilaian kinerja Pegawai Negeri Sipil (PNS) yang tercantum pada Peraturan Pemerintah (PP) Nomor 46 tahun 2011 tentang Penilaian Prestasi Kerja Pegawai Negeri Sipil, yaitu: (a) 91 - keatas dinilai "Sangat Baik"; (b) 76-90 dinilai Baik; (c) 61-75 dinilai "Cukup"; (d) 51-60 dinilai "Kurang'; dan, (e) 50 ke bawah dinilai "Buruk".

Penilaian ini selanjutnya dihubungkan dengan indikator kinerja utama, yaitu kualitas kerja, kuantitas kerja, pelaksanaan tugas, dan tanggungjawab (Wirawan, 2012; Mangkunegara, 2010). Kualitas kerja adalah seberapa baik seorang karyawan mengerjakan apa yang seharusnya dikerjakan; kuantitas kerja adalah seberapa lama seorang pegawai bekerja dalam satu harinya. kuantitas kerja ini dapat dilihat dari kecepatan kerja masing-masing pegawai; pelaksanaan tugas yaitu bagaimana karyawan mampu melakukan tugasnya dengan akurat atau tidak ada kesalahan; serta tanggungjawab terhadap pekerjaan adalah kesadaran akan kewajiban karyawan untuk melaksanakan pekerjaan yang diberikan perusahaan.

\section{Karakteristik Individu}

Salah satu faktor yang dinilai mempengaruhi kinerja seorang pegawai adalah karakteristik individu. Setiap orang mempunyai pandangan, tujuan, kebutuhan dan kemampuan yang berbeda satu sama lain sehingga memiliki karakteristik individu yang berbeda antara mereka. Karakteristik individu diantaranya meliputi usia, masa kerja, status kepegawaian, keterampilan, dan motivasi. 
Perbedaan ini umumnya terbawa dalam dunia kerja, meskipun bekerja ditempat yang sama (Dessler, 2016; Robbins \& Judge, 2013). Faktor karakteristik individu ini karenanya ditengarai merupakan unsur yang berfungsi membentuk kinerja seseorang menjalankan pekerjaan atau tugasnya, tanpa terkecuali dengan kinerja bidan di rumah sakit.

Usia adalah lama hidup seseorang yang dihitung sejak lahir sampai dengan penelitian ini dilakukan. Hubungan antara usia dan kinerja karyawan telah diuji oleh beberapa peneliti. Hasil riset von Bonsdorff et al. (2016) serta Suswati (2015) memperoleh hasil bahwa usia memiliki hubungan yang positif terhadap kinerja. Namun sebaliknya, studi Vu et al. (2019) menemukan usia memiliki hubungan negatif terhadap kinerja Dengan demikian, masih terdapat gap riset terkait hubungan usia dan kinerja pegawai, sehingga dimunculkan hipotesis penelitian:

H1: Usia berpengaruh signifikan terhadap kinerja bidan.

Masa kerja adalah lamanya seorang bidan bekerja dalam melaksanakan kegiatan keprofesian kebidanan dan dapat di ukur dengan waktu. Studi milik Maryam (2014) serta Suswati (2015) menemukan masa kerja memiliki hubungan positif dan signifikan terhadap kinerja pegawai. Studi Sugito et al. (2019) di sisi lain memperoleh hasil terdapat pengaruh negatif dari masa kerja terhadap kinerja guru. Sementara itu, studi Lasut et al. (2017) menggunakan uji beda menemukan tidak ada perbedaan kinerja pegawai dilihat dari masa kerja. Dengan demikian, masih terdapat gap riset terkait hubungan masa kerja dan kinerja pegawai, sehingga dimunculkan hipotesis penelitian:

H2: Masa kerja berpengaruh signifikan terhadap kinerja bidan.
Status kepegawaian adalah kedudukan atau posisi seorang bidan dalam pelaksanaan tugas keprofesian di rumah sakit yang dibuktikan dengan SK. Studi milik Aspita \& Sugiono (2018) serta milik Ola et al. (2019) memperoleh pengaruh parsial bersifat positif dan signifikan. Sebaliknya, studi Hendrajana et al. (2017) menemukan hasil bahwa status kepegawaian memiliki pengaruh negatif dan signifikan terhadap kinerja pegawai. Dengan demikian, masih terdapat gap riset terkait hubungan status kepegawaian dan kinerja pegawai, sehingga dimunculkan hipotesis penelitian:

H3: Status kepegawaian memiliki pengaruh signifikan terhadap kinerja bidan.

Keterampilan yaitu keahlian, kecakapan dan kompetensi seorang bidan di dalam menjalankan profesi atau tugasnya yang meliputi pemberian asuhan kepada ibu bersalin, ibu nifas dan asuhan bayi baru lahir. Studi Kasmini et al. (2017) serta Saban et al. (2020) memperoleh temuan empisis bahwa keterampilan mempunyai pengaruh positif dan signifikan terhadap kinerja pegawai. Studi Dewi (2020) mempertegas adanya pengaruh yang positif dan signifikan oleh keterampilan terhadap kinerja pegawai. Berdasarkan hasil-hasil tersebut dimunculkan hipotesis penelitian:

H4: Keterampilan berpengaruh signifikan terhadap kinerja bidan.

Motivasi adalah stimulus atau dorongan yang berpengaruh serta membangkitkan semangat dari dalam diri bidan dan di luar yang berhubungan dengan lingkungan kerja. Temuan-temuan empiris milik Sugito et al. (2019) ataupun Kasmini et al. (2017) menunjukkan bahwa motivasi mempunyai pengaruh positif terhadap kinerja pegawai. Studi empiris Paais \& Pattiruhu (2020) juga menemukan adanya pengaruh positif dan 
signifikan dari motivasi atas kinerja pegawai. Berdasarkan sejumlah temuan itu, maka dimunculkan hipotesis penelitian:

H5: Motivasi memiliki pengaruh signifikan terhadap kinerja bidan.

\section{Faktor Ekstrinsik}

Selain karakteristik individu, faktor ekstrinsik juga dinilai berpengaruh terhadap kinerja seorang individu. Di dalam organisasi faktor ekstrinsik merupakan faktor yang berada diluar dari individu yang dianggap juga mempengaruhi kinerja dari seseorang (Dessler, 2016; Sutrisno, 2015; Robbins \& Judge, 2013). Faktor ekstrinsik yang mempengaruhi kinerja seseorang dapat berasal dari organisasi dan lingkungan organisasi itu. Dalam penelitian ini faktor ekstrinsik yang diteliti yaitu imbalan, beban kerja, supervisi dan pelatihan.

Imbalan merupakan kompensasi dalam bentuk upah, insentif, dan reward yang diberikan kepada bidan setelah mereka memberikan kemampuan, keahlian serta usahanya kepada organisasi. Hasil riset Ramli (2018) menemukan imbalan atau kompensasi secara parsial berpengaruh signifikan atas kinerja karyawan. Studi-studi empiris milik Aspita \& Sugiono (2018) serta Saban et al. (2020) memperoleh bahwa imbalan memiliki hubungan yang positif dan signifikan terhadap kinerja pegawai. Dengan demikian maka dimunculkan hipotesis penelitian:

H6: Imbalan memiliki pengaruh signifikan terhadap kinerja bidan.

Beban kerja adalah tanggung jawab seorang bidan yang memiliki kemampuan dan kewenangan dalam melaksanakan kegiatan keprofesian kebidanan berdasarkan ilmu yang dimiliki sesuai tupoksi dan di luar tupoksi dalam jangka waktu tertentu. Studi riset milik Siswanto et al. (2019) serta Dhelvia \& Soegoto (2018) menemukan bahwa beban kerja memiliki pengaruh yang positif dan signifikan atas kinerja karyawan. Namun sebaliknya, studi empiris milik Soelton et al. (2018) memperoleh bahwa beban kerja tidak memiliki pengaruh terhadap kinerja pegawai. Dengan demikian dimunculkan hipotesis penelitian:

H7: Beban kerja berpengaruh signifikan terhadap kinerja bidan.

Supervisi adalah pengamatan secara langsung dan berkala oleh atasan terhadap pekerjaan yang dilaksanakan oleh bawahan. Penelitian Rahmawan \& Masruroh (2020) serta Harpis \& Bahri (2020) mengidentifikasi pelaksanaan supervisi memiliki pengaruh yang signifikan terhadap kinerja karyawan. Temuan empiris dari studi Zulkifli \& Gani (2018) juga memperoleh bahwa supervisi memiliki pengaruh positif dan signifikan atas kinerja pegawai. Atas pemikiran tersebut, dimunculkan hipotesis penelitian:

H8: Supervisi memiliki pengaruh signifikan terhadap kinerja bidan.

Pelatihan adalah keterlibatan bidan dalam kegiatan pendidikan non formal yang pernah diikuti dalam waktu singkat dalam rangka meningkatkan pengetahuan dan keterampilan keprofesian kebidanan dalam bekerja. Studi milik Guan \& Frenkel (2019) menemukan bahwa program pelatihan yang diikuti memiliki pengaruh yang positif terhadap kinerja pegawai. Temuan empiris dari studi empiris milik Sendawula et al. (2018) serta Mukminin et al. (2020) juga mengidentifikasi bahwa pelatihan memiliki pengaruh yang positif dan signifikan terhadap kinerja pegawai. Dengan demikian maka dimunculkan hipotesis penelitian:

H9: Pelatihan memiliki pengaruh signifikan terhadap kinerja bidan. 


\section{METODE PENELITIAN}

Penelitian survey ini menganalisis pengaruh karakteristik individu (umur, masa kerja, status kepegawaian, keterampilan, motivasi) dan faktor ekstrinsik (imbalan, beban kerja, supervisi dan pelatihan) terhadap kinerja bidan.

Responden adalah seluruh bidan yang bertugas di ruang kebidanan rawat inap Rumah Sakit Umum Daerah Langsa yang berjumlah 47 orang. Pengumpulan data primer menggunakan kuisioner, dan didukung oleh wawancara langsung.

\section{Pengukuran Variabel}

Kinerja bidan dinilai menggunakan kuisioner yang berisi pernyataan mengenai standar kerja bidan berdasarkan Keputusan Menteri Kesehatan RI no 900/MENKES/SK/ VII/2002 yang terdiri dari asuhan persalinan, asuhan nifas dan asuhan bayi baru lahir dengan kategori 'Kurang Baik' jika total skor $<75$, serta kategori 'Baik' jika total skor $\geq 75$.

Pengukuran variabel usia menggunakan dua kategori, adalah: (a) < 35 tahun; dan, (b) $\geq 35$ tahun. Pengukuran masa kerja menggunakan dua kategori, yaitu: (a) baru < 5 tahun; serta, (b) Lama $\geq 5$ tahun. Status kepegawaian diukur dengan menggunakan tiga kategori, adalah: (a) ASN; (b) honor; dan, (c) kontrak.

Untuk variabel-variabel keterampilan, motivasi, imbalan, beban kerja, supervise dan pelatihan, diukur melalui 5-skala Likert, yaitu rentang skor 1 untuk jawaban 'Tidak Pernah' atau 'Rendah Sekali' sampai skor 5 untuk jawaban 'Selalu' atau 'Sangat Tinggi'. Variabel keterampilan diukur menggunakan 23 indikator dengan kategori 'Tidak Baik' jika total skor $\leq 69$, serta kategori 'Baik' jika total skor > 69. Variabel motivasi diukur menggunakan 10 indikator dengan kategori 'Tidak Baik' jika total skor $\leq 30$, serta kategori 'Baik' jika total skor $>30$. Variabel imbalan diukur menggunakan 3 indikator dengan kategori 'Tidak Baik' jika total skor $\leq 9$, serta kategori 'Baik' jika total skor $>9$. Variabel beban kerja diukur menggunakan 3 indikator dengan kategori 'Tidak Baik' jika total skor $\leq 9$, serta kategori 'Baik' jika total skor > 9. Variabel supervisi diukur menggunakan 3 indikator dengan kategori 'Tidak Baik' jika total skor $\leq 9$, serta kategori 'Baik' jika total skor $>9$.

\section{Metode Analisis Data}

Ada beberapa tahapan dalam proses analisis data yang dilakukan. Tahap analisis univariat yang djalankan untuk memperoleh gambaran mengenai distribusi frekuensi untuk masing-masing variabel yang dianalisis. Tahap berikutnya yaitu melakukan uji chisquare untuk menganaliis hubungan masingmasing variabel independen dengan variabel dependen, dengan batas signifikansi $(\alpha)$ sebesar 0,05. Hasil uji statistik dikatakan signifikan apabila nilai $p$ lebih kecil dari $\alpha$ $(0,05)$; sebaliknya, dikatakan tidak signifikan apabila nilai $p$ lebih kecil dari $\alpha(0,05)$.

Tahap terakhir yaitu melakukan analisis regresi logistik ganda, dengan tujuan menganalisis pengaruh lebih dari satu variabel independen terhadap variabel dependen. Uji regresi logistik dengan menggunakan metode Backward $L R$ dimana variabel yang tidak signifikan dengan nilai $\mathrm{p}>0,05$ akan dikeluarkan secara bertahap (step by step). Sebelum uji ini dilakukan, terlebih dahulu dilakukan pemilihan variabel yang memenuhi syarat yaitu jika nilai $p<0,05$ diperoleh saat uji chi-square akan dimasukkan ke dalam analisis multivariat.

\section{HASIL ANALISIS}

Hasil olah data berkaitan dengan distribusi frekuensi serta uji chi-square dirangkum dalam Tabel 1. 
Tabel 1. Hasil Uji Pengaruh Karakteristik Individu dan Kinerja Bidan

\begin{tabular}{|c|c|c|c|c|c|c|c|}
\hline \multirow{3}{*}{ Variabel } & \multicolumn{4}{|c|}{ Kinerja } & \multirow{2}{*}{\multicolumn{2}{|c|}{ Jumlah }} & \multirow{3}{*}{$p$-valuc } \\
\hline & \multicolumn{2}{|c|}{ Kurang Baik } & \multicolumn{2}{|c|}{ Baik } & & & \\
\hline & $\mathrm{N}$ & $\%$ & $\mathrm{~N}$ & $\%$ & $\mathrm{~N}$ & $\%$ & \\
\hline \multicolumn{8}{|l|}{ Umur } \\
\hline$<35$ tahun & 7 & 70,0 & 3 & 30,0 & 10 & 100,0 & \multirow[t]{2}{*}{0,719} \\
\hline$\geq 35$ tahun & 22 & 59,5 & 15 & 40,5 & 37 & 100,0 & \\
\hline \multicolumn{8}{|l|}{ Masa Kerja } \\
\hline$<5$ tahun & 7 & 77,8 & 2 & 22,2 & 9 & 100,0 & \multirow[t]{2}{*}{0,449} \\
\hline$\geq 5$ tahun & 22 & 57,9 & 16 & 42,1 & 38 & 100,0 & \\
\hline \multicolumn{8}{|c|}{ Status Kepegawaian } \\
\hline Kontrak & 23 & 92,0 & 2 & 8,0 & 25 & 100,0 & \multirow{3}{*}{0,0001} \\
\hline Honor & 1 & 50,0 & 1 & 50,0 & 2 & 100,0 & \\
\hline ASN & 5 & 25,0 & 15 & 75,0 & 20 & 100,0 & \\
\hline \multicolumn{8}{|l|}{ Keterampilan } \\
\hline Tidak baik & 24 & 77,4 & 7 & 22,6 & 31 & 100,0 & \multirow[t]{2}{*}{0,0002} \\
\hline Baik & 5 & 31,2 & 11 & 68,8 & 16 & 100,0 & \\
\hline \multicolumn{8}{|l|}{ Motivasi } \\
\hline Tidak baik & 24 & 88,9 & 3 & 11,1 & 27 & 100,0 & \multirow[t]{2}{*}{0,0001} \\
\hline Baik & 5 & 25,0 & 15 & 75,0 & 20 & 100,0 & \\
\hline
\end{tabular}

Sumber: Data diolah, 2020.

Tabel 2. Hasil Uji Pengaruh Faktor Ekstrinsik dan Kinerja Bidan

\begin{tabular}{|c|c|c|c|c|c|c|c|}
\hline \multirow{3}{*}{ Variabel } & \multicolumn{4}{|c|}{ Kinerja } & \multirow{2}{*}{\multicolumn{2}{|c|}{ Jumlah }} & \multirow{3}{*}{ p-value } \\
\hline & \multicolumn{2}{|c|}{ Kurang Baik } & \multicolumn{2}{|c|}{ Baik } & & & \\
\hline & $\mathrm{N}$ & $\%$ & $\mathrm{~N}$ & $\%$ & $\mathrm{~N}$ & $\%$ & \\
\hline \multicolumn{8}{|l|}{ Imbalan } \\
\hline Tidak baik & 10 & 71,4 & 4 & 28,6 & 14 & 100,0 & \multirow[t]{2}{*}{0,372} \\
\hline Baik & 19 & 57,6 & 14 & 42,4 & 33 & 100,0 & \\
\hline \multicolumn{8}{|l|}{ Beban Kerja } \\
\hline Tidak baik & 7 & 50,0 & 7 & 50,0 & 14 & 100,0 & \multirow[t]{2}{*}{0,282} \\
\hline Baik & 22 & 66,7 & 11 & 33,3 & 33 & 100,0 & \\
\hline \multicolumn{8}{|l|}{ Supervisi } \\
\hline Tidak baik & 22 & 75,9 & 7 & 24,1 & 29 & 100,0 & \multirow[t]{2}{*}{0,011} \\
\hline Baik & 7 & 38,9 & 11 & 61,1 & 18 & 100,0 & \\
\hline \multicolumn{8}{|l|}{ Pelatihan } \\
\hline Tidak pernah & 24 & 72,7 & 9 & 27,3 & 33 & 100,0 & \multirow[t]{2}{*}{0,031} \\
\hline Jarang & 5 & 35,7 & 9 & 64,3 & 14 & 100,0 & \\
\hline
\end{tabular}

Sumber: Data diolah, 2020.

Hasil distribusi frekuensi pada Tabel 1 untuk variabel-variabel dari karakteristik individu mengindikasikan bahwa mayoritas responden memiliki umur lebih besar atau sama dengan 35 tahun (37 orang atau 78,7 persen), masa kerja lebih lama atau sama dengan 5 tahun (38 orang atau 80,9 persen), status kepegawaian sebagai pegawai kontrak (25 orang atau 53,2 persen), tingkat keterampilan pada level tidak baik (31 orang atau 66,0 persen), serta motivasi kerja pada level tidak baik (27 orang atau 57,4 persen). 
Hasil uji chi-square dalam Tabel 1 mengenai hubungan antara variabel-variabel dari karakteristik individu (yaitu: umur, masa kerja, status kepegawaian, keterampilan, dan motivasi) dengan kinerja bidan. Berdasarkan kriteria penilaian diperoleh ada tiga variabel independen dari karakteristik individu yang memiliki pengaruh signifikan terhadap kinerja bidan, yaitu status kepegawaian $(p=0,0001<$ $0,05)$, keterampilan $(p=0,0002<0,05)$, serta motivasi $(p=0,0001<0,05)$. Sementara dua variabel independen lainnya tidak memiliki pengaruh yang signifikan, yaitu usia ( $p=$ $0,719>0,05)$, serta masa kerja $(p=0,449>$ $0,05)$. Hasil penelitian ini membuktikan hipotesis ketiga (H3), hipotesis keempat (H4), dan hipotesis kelima (H5) bisa diterima; dan menolak hipotesis pertama (H1), dan hipotesis kedua (H2).

Berikutnya, hasil distribusi frekuensi pada Tabel 2 untuk variabel-variabel dari faktor ekstrinsik menunjukkan mayoritas responden memiliki imbalan pada level baik (33 orang atau 70,2 persen), beban kerja pada level baik (33 orang atau 70,2 persen), supervisi pada level tidak baik (29 orang atau 61,7 persen), serta pelatihan pada level tidak pernah (33 orang atau 70,2 persen).

Tabel 2 juga merangkum hasil uji chisquare mengenai hubungan antara variabelvariabel dari faktor ekstrinsik (yaitu: imbalan, beban kerja, supervisi, dan pelatihan) dengan kinerja bidan. Berdasarkan kriteria penilaian diperoleh ada dua variabel independen dari faktor ekstrinsik yang memiliki pengaruh yang signifikan terhadap kinerja bidan, yaitu supervisi $(p=0,011<0,05)$, serta pelatihan $(p$ $=0,031<0,05)$. Sementara dua variabel independen lainnya tidak memiliki pengaruh yang signifikan, yaitu imbalan $(p=0,372>$ $0,05)$, serta beban kerja $(p=0,282>0,05)$. Hasil penelitian ini membuktikan hipotesis ke delapan (H8) dan hipotesis ke sembilan (H9) bisa diterima; serta menolak hipotesis ke enam (H6), dan hipotesis ketujuh (H7).

Berdasarkan hasil-hasil dalam Tabel 1 dan Tabel 2 diperoleh terdapat lima variabel independen yang terpilih untuk dimasukkan ke dalam uji multivariat karena memiliki $p$ value dibawah $\alpha(0,05)$. Kelima variabel itu adalah status kepegawaian, keterampilan, motivasi, supervisi, serta pelatihan; yang selanjutnya dianalisis menggunakan teknik uji regresi logistik ganda dengan metode Backward LR dimana variabel yang tidak signifikan dengan nilai $\mathrm{p}>0,05$ akan dikeluarkan secara bertahap (step by step).

Hasil akhir dari analisis regresi logistik berganda tentang pengaruh antara variabel independen terhadap variabel dependen dalam penelitian ini dirangkum dalam Tabel 3. Hasil itu menunjukkan ada pengaruh dari motivasi, keterampilan dan supervisi terhadap kinerja bidan di RSUD Kota Langsa dengan p-value $<0,005$. Dari hasil uji regresi logistik ganda ini juga diidentifikasi bahwa variabel yang dominan memengaruhi kinerja bidan adalah motivasi dengan nilai Exp $B$ sebesar 27,784 yang berarti bidan memiliki motivasi kerja baik sebesar 27,784 kali kemungkinan kinerja baik di RSUD Kota Langsa dibandingkan dengan motivasi tidak baik.

\section{Tabel 3. Hasil Analisis Regresi Logistik Berganda}

\begin{tabular}{lcccc}
\hline \multicolumn{1}{c}{ Variabel } & B & p-value & Exp B & $95 \% \mathrm{Cl}$ \\
\hline Constant & $-3,896$ & & & \\
Motivasi & 3,324 & 0,001 & 27,784 & $3,870-199,483$ \\
Keterampilan & 2,281 & 0,023 & 9,784 & $1,362-70,256$ \\
Supervisi & 2,055 & 0,039 & 7,807 & $1,114-54,694$ \\
\hline
\end{tabular}

Sumber: Data diolah, 2021. 


\section{Pembahasan}

Hasil yang diperoleh membuktikan tidak ada pengaruh usia terhadap kinerja bidan pada obyek penelitian. Hal ini berarti bahwa kinerja pegawai tidaklah ditentukan secara nyata oleh faktor usia pegawai yang bersangkutan, sehingga tidak sesuai dengan temuan riset von Bonsdorff et al. (2016), Suswati (2015) serta Vu et al. (2019). Hasil ini menolak anggapan bahwa semakin tua seorang bidan maka semakin merosot kinerjanya, karena keterampilan, kecepatan, kecekatan kekuatan dan koordinasi dirinya menurun dengan berjalannya waktu. Bidan yang dianggap sudah berumur juga kerap bersikap kurang luwes dan menolak penerapan teknologi baru. Tetapi ada sejumlah kualitas positif yang dimiliki oleh bidan yang lebih tua berdasarkan pengalaman, pertimbangan, etika kerja yang kuat serta komitmennya terhadap mutu pekerjaannya.

Hasil yang diperoleh ini membuktikan bahwa tidak ada pengaruh yang signifikan dari masa kerja dengan kinerja bidan, sesuai temuan empiris milik Lasut et al. (2017) tetapi berbeda dengan temuan Maryam (2014), Suswati (2015) dan Sugito et al. (2019). Dengan demikian, hasil ini menolak argumen bahwa semakin lama masa kerja seorang pegawai maka akan menghasilkan kinerja yang tinggi. Masa kerja menjadi salah satu faktor yang dapat meningkatkan kinerja sekaligus dapat menurunkan kinerja karyawan jika tidak diperhatikan secara benar oleh pihak perusahaan (Luthans et al., 2015; Dessler, 2016). Masa kerja bidan sebagian besar lama namun tidak menyebabkan kinerja bidan baik. Faktor tidak adanya hubungan antara masa kerja bisa disebabkan karena terjadi kejenuhan terhadap rutinitas pekerjaan dan kebiasaan dalam memberikan asuhan kebidanan, juga karena kurangnya pembinaan mengenai pelayanan dan asuhan kebidanan terbaru terhadap para bidan. Bertambahnya lama kerja seorang bidan sebaiknya disertai kegiatan untuk meningkatkan keterampilan, pengetahuan, dan kemampuan setiap individu agar tidak terjadi kejenuhan terhadap rutinitas sehingga kualitas pelayanan kebidanan menjadi lebih baik.

Hasil empiris lain menunjukkan bahwa ada hubungan positif dan signifikan antara status kepegawaian dengan kinerja bidan, sesuai dengan temuan empiris milik Aspita \& Sugiono (2018) serta Ola et al. (2019). Status kepegawaian yang dimiliki bidan sebagian besar adalah kontrak. Setiap individu dalam masyarakat memiliki status sosialnya masingmasing. Status merupakan perwujudan atau pencerminan dari hak dan kewajiban individu dalam tingkah lakunya (Sutrisno, 2015; Dessler, 2016). Status sosial sering pula disebut sebagai kedudukan atau posisi, peringkat seseorang di dalam kelompok masyarakatnya. Pada semua sistem sosial tentu terdapat berbagai macam kedudukan atau status. Dan setiap status memiliki peran dan tanggungg jawab yang berbeda pula. Demikian pula dengan status kepegawaian seorang bidan di rumah sakit memiliki peran dan tangggung jawab yang berbeda dan mempengaruhi kinerja bidan tersebut.

Hasil empiris juga menemukan bahwa ada hubungan yang signifikan antara keterampilan dengan kinerja bidan. Hasil ini menegaskan temuan empiris milik Kasmini et al. (2017), Saban et al. (2020) serta Dewi (2020). Hal ini karena bidan merupakan suatu profesi, dimana profesi merupakan suatu pekerjaan yang menuntut keahlian atau keterampilan dari pelakunya. Dengan keterampilan kerja yang dimiliki seorang bidan, maka pekerjaan yang menjadi tanggung jawabnya dapat terselesaikan secara efektif dan efisien. Hal ini sejalan dengan pemahaman bahwa keterampilan atau kompetensi adalah suatu karakteristik dasar dari seseorang yang memungkinkannya 
memberikan kinerja unggul dalam pekerjaan, peran, atau situasi tertentu (Yuniarsih, 2013; Batbuall, 2019). Keterampilan adalah hal-hal yang orang bisa lakukan dengan baik. Keterampilan bidan sebagai tenaga pelayanan kesehatan sangat menentukan keberhasilan pelaksanaan perannya di tengah masyarakat. Apabila seorang tenaga bidan mempunyai kemampuan yang baik tentang pelayanan kesehatan diharapkan mampu melakukan tugas dan fungsinya dengan baik pula. Keterampilan sebagai ungkapan dan perwujudan diri individu termasuk kebutuhan pokok manusia yang bilamana terwujud memberikan rasa kepuasan dan keberhasilan yang mendalam, yang pada akhirnya dapat menentukan dan meningkatkan makna hidup manusia dengan segala kompleksitasnya.

Hasil empiris berikutnya memperoleh bahwa ada hubungan yang signifikan antara motivasi dengan kinerja bidan, yang mana menegaskan temuan milik Sugito et al. (2019), Kasmini et al. (2017), serta Paais \& Pattiruhu (2020). Motivasi kerja merupakan salah satu faktor yang turut menentukan kinerja seseorang maupun lingkungannya dimana besar ataupun kecilnya pengaruh tergantung pada seberapa banyak intensitas motivasi yang diberikan (Robbins \& Judge, 2013; Sutrisno, 2015). Orang yang memiliki motivasi seperti ini biasanya memiliki visi yang jauh ke depan. Baginya bekerja bukan sekadar untuk memperoleh sesuatu (uang, harga diri, kebanggaan, prestasi) tetapi adalah proses belajar dan proses yang harus dilaluinya untuk mencapai misi hidupnya. Demikian juga keberadaan bidan, apabila memiliki motivasi kerja baik akan dapat mencapai target cakupan yang ditetapkan dalam program pelayanan kesehatan ibu dan anak. Untuk meningkatkan motivasi bidan dalam meningkatkan kinerjanya khususnya pelayanan kesehatan ibu dan anak agar terlaksana dengan baik, maka perlu dukungan dari berbagai pihak, khususnya atasan atau diberikan penghargaan terhadap kinerja bidan melalui pemilihan bidan teladan. Perilaku dari bidan akan baik berasal dari motivasinya yang memang baik. Jadi apabila seorang bidan memiliki motivasi yang baik untuk mencapai tujuannya, maka kinerja akan meningkat.

Hasil empiris berikutnya menunjukkan tidak ada hubungan yang signifikan antara imbalan dengan kinerja. Hasil ini berlawanan dengan hasil riset Ramli (2018), Aspita \& Sugiono (2018) serta Saban et al. (2020). Gaji atau imbalan finansial yang diterima oleh seseorang bagi jasa-jasa yang diberikannya kepada organisasi dapat mengambil berbagai bentuk, jumlah imbalan finansial yang layak diterimanya berdasarkan jenjang pendidikan, pengetahuan, keterampilan, sifat pekerjaan, besarnya tanggung jawab dan wewenang (Robbins \& Judge, 2013; Dessler, 2016). Terdapat pernyataan bahwa tidak ada satu organisasi yang dapat memberikan kekuatan baru kepada pegawainya atau meningkatkan produktivitas, jika tidak memiliki sistem kompensasi dan gaji yang realistis. Apabila sistem dari kompensasi dan penggajian terimplementasi dengan benar maka akan memotivasi pegawai. Bidan mengemukakan bahwa gaji yang diterima sudah sesuai, namun jasa medik yang mereka terima dirasa kurang dan tidak sesuai dengan beban kerja, khususnya hal ini sangat dirasakan oleh bidan dengan status honor dan kontrak.

Penelitian ini juga menemukan bahwa tidak ada hubungan yang signifikan antara beban kerja dengan kinerja bidan, atau bahwa hasil ini menolak argument bahwa adanya hubungan yang signifikan antara kelelahan kerja akibat beban kerja dilihat dari jumlah pasien yang meningkat dengan kinerja. Hasil ini seusai dengan temuan studi empiris milik Soelton et al. (2018); namun bertentangan dengan hasil studi milik Siswanto et al. (2019) serta Dhelvia \& Soegoto (2018). 
Bidan melaksanakan tugasnya sesuai dengan keterampilan dan tupoksi. Beban kerja yang dirasakan oleh bidan yang bertugas di ruang rawat inap kebidanan setelah terjadinya pengurangan karyawan yang selama ini setiap shift berjumlah 5-6 orang. Tenaga kesehatan khususnya bidan dan perawat, dimana analisa beban kerjanya dapat dilihat dari aspek-aspek seperti tugas-tugas yang dijalankan berdasarkan fungsi utamanya, begitupun tugas tambahan yang dikerjakan, jumlah pasien yang harus dirawat, kapasitas kerjanya sesuai dengan pendidikan yang ia peroleh, waktu kerja yang digunakan untuk mengerjakan tugasnya sesuai dengan jam kerja yang berlangsung setiap hari, serta kelengkapan fasilitas yang dapat membantu perawat menyelesaikan kerjanya dengan baik.

Hasil empiris selanjutnya menemukan bahwa ada hubungan yang signifikan antara supervisi bidan dengan kinerja bidan, sejalan denga temuan empiris milik Rahmawan \& Masruroh (2020), Harpis \& Bahri (2020) serta Zulkifli \& Gani (2018). Supervisi adalah salah satu bagian proses atau kegiatan dari fungsi pengawasan ataupun pengendalian (controlling), serta sumber dari sekumpulan kegiatan pengambilan keputusan yang terkait erat dengan aktivitas perencanaan dan pengorganisasian kegiatan dan informasi dari kepemimpinan dan pengevaluasian setiap kinerja karyawan (Batbuall, 2019; Luthans et al., 2015). Supervisi merupakan bagian penting dari manajemen keperawatan, karena dengan supervisi dapat mengatasi masalah dalam organisasi dengan cepat. Tugas pengawasan ataupun supervisi tidak bisa dipisahkan dari fungsi kepemimpinan. Supervisor atau pengawas di mata karyawan dianggap sebagai figur ayah dengan peran yang bukan hanya mengawasi, mengarahkan juga harus bisa menampung segala keluhan baik berkaitan dengan pekerjaan maupun masalah-masalah pribadi yang menghambat di saat bekerja. Dengan adanya supervisi diharapkan memberikan pengaruh terhadap pelaksanaan asuhan kebidanan yang baik sehingga penilaian kinerja yang profesional dan legal bisa dipertanggung jawabkan.

Terakhir, hasil empiris dalam penelitian ini membuktikan bahwa adanya hubungan yang signifikan antara pelatihan dengan kinerja bidan. Hasil ini sejalan dengan temuan studi Guan \& Frenkel (2019), Sendawula et al. (2018) serta Mukminin et al. (2020) Hal ini berarti makin sering bidan mendapatkan pelatihan yang sesuai dengan tugas-tugasnya maka makin meningkat kinerjanya. Pelatihan sebagai bagian pendidikan yang menyangkut proses belajar untuk memperoleh dan meningkatkan keterampilan diluar sistem pendidikan yang berlaku dalam waktu yang relatif singkat dengan metode yang lebih mengutamakan pada praktik daripada teori (Sutrisno, 2015; Dessler, 2016). Pelatihan membantu para pegawai mengembangkan berbagai keterampilan tertentu yang memungkinkannya untuk berhasil dalam pekerjaannya saat ini dan mengembangkan pekerjaannya di masa mendatang (Luthans, et al., 2015; Robbins \& Judge, 2013). Dengan pelatihan bidan dapat menambah ilmu dan pengetahuannya khususnya dalam pelayanan kebidanan. Sehingga sudah jelas bidan yang pernah mengikuti pelatihan cenderung lebih tinggi kinerjanya dari bidan yang belum pernah mengikuti pelatihan. Sesuai dengan kebijakan penempatan bidan merupakan salah satu upaya terobosan dalam mempercepat penurunan AKI, AKB dan tingkat fertilitas maka bidan perlu dibina secara mantap terstruktur agar bidan mampu menunjukkan kinerja yang tinggi. Pembinaan yang mantap dapat menjadikan bidan konsisten mempunyai tujuan terarah kepada penurunan AKI, AKB yang punya semangat baja, terampil dan kegiatan program KIA dengan kualitas tenaga barisan terdepan. 


\section{SIMPULAN}

Hasil penelitian menyimpulkan hanya tiga variabel independen dari karakteristik individu yang terbukti berpengaruh secara signifikan terhadap kinerja bidan, yaitu status kepegawaian, keterampilan, dan motivasi. Sementara itu, hanya ada dua variaabel independen dari faktor ekstrinsik terbukti berpengaruh secara signifikan atas kinerja bidan, yaitu supervisi dan pelatihan.

Berdasarkan kesimpulan tersebut, direkomendasikan beberapa hal. Pertama, perlu dilakukannya penilaian kinerja bidan secara objektif berdasarkan profesi kebidanan sehingga dapat diketahui kemampuan dan keterampilan bidan serta motivasinya. Dengan penilaian ini dapat dijadikan rekomendasi dalam perencanaan kegiatan pelatihan bagi bidan dalam peningkatan kemampuan dan keterampilan seperti pelatihan penanganan pre-eklamsi dan/atau eklamsi, penanganan perdarahan selama kehamilan dan persalinan, pelatihan APN (Asuhan Persalinan Normal), penanganan bayi asfiksia, penanganan kegawatdaruratan obstetri dan neonatal.

Rekomendasi kedua bahwa perlu dilakukan proses supervisi khususnya pada pelayanan kebidanan dan asuhan kebidanan sehingga bidan yang memiliki kinerja baik dapat diberikan reward dalam bentuk penghargaan, peningkatan karier, pemberian hadiah dan memberikan punishment pada bidan yang memiliki kinerja kurang baik dalam bentuk teguran secara lisan dan tulisan, pemindahan tempat tugas.

Rekomendasi ketiga yaitu memberikan kesempatan yang lebih luas bagi bidan untuk terus berkembang dan mendapat peluang yang lebih terbuka untuk promosi, memperbaiki kondisi kerja rumah sakit agar bidan merasa aman serta nyaman di dalam bekerja, meningkatkan dukungan dari atasan, terutama atas kemajuan dan keberhasilan bidan.

\section{REFERENSI}

Andayani, I., \& Tirtayasa, S. (2019). Pengaruh kepemimpinan, budaya organisasi, dan motivasi terhadap kinerja pegawai. Maneggio: Jurnal Ilmiah Magister Manajemen, 2(1), 4554. doi: 10.30596/maneggio.v2i1.3367.

Ardiansyah, Y., \& Sulistiyowati, L. H. (2018). Pengaruh kompetensi dan kecerdasan emosional terhadap kinerja pegawai. Jurnal Inspirasi Bisnis dan Manajemen, 2(2), 91-100. doi: 10.33603/jibm.v2i1.1064.

Aspita, M., \& Sugiono, E. (2018). Pengaruh jenjang karir, kompensasi finansial dan status karyawan terhadap kinerja karyawan Bank Rakyat Indonesia Cabang Daan Mogot. Oikonomia: Jurnal Manajemen, 14(1), 1-14. Retrieved from: http://journal.unas.ac. id/oikonamia/article/view/510.

Azwar, A. (2014). Pengantar administrasi kesehatan. Binarupa Aksara.

Batbuall, B. (2019). Self management untuk meningkatkan kinerja bidan. Penerbit Adab.

Buil, I., Martínez, E., \& Matute, J. (2019). Transformational leadership and employee performance: The role of identification, engagement and proactive personality. International Journal of Hospitality Management, 77(January), 64-75. doi: 10.1016/j.ijhm. 2018.06.014.

Dessler, G. (2016). Human Resource Management (15 ${ }^{\text {th }}$ Edition). Pearson.

Dewi, C. A. (2020). Pengaruh pengalaman kerja dan keterampilan terhadap kinerja karyawan di CV. Grammes Jewelry Kerobokan. Majalah Ilmiah Widyacakra, 3(1), 84-90. Retrieved from: http://Jurnal.Stiesahidbali.Ac.Id/Index. Php/MIW/Article/View/67.

Dhelvia, R., \& Soegoto, H. S. (2018). The influence workload and competence on employee performance in PT. $\mathrm{X}$ Finance. Advances in Social Science, Education and Humanities Research, 225, 135-138. Retrieved from: https:// 
www.atlantis-press.com/article/ 25906815.pdf.

Diamantidis, A. D., \& Chatzoglou, P. (2019). Factors affecting employee performance: A empirical approach. International Journal of Productivity and Performance Management, 68(1), 171-193. doi: 10.1108/IJPPM-01-20180012 .

Guan, X., \& Frenkel, S. (2019). How perceptions of training impact employee performance: Evidence from two Chinese manufacturing firms. Personnel Review, 48(1), 163-183. Doi: 10.1108/PR-05-2017-0141.

Harpis, M., \& Bahri, S. (2020). Pengaruh fasilitas kerja, pengawasan dan kompensasi terhadap kinerja pegawai pada Dinas Pekerjaan Umum dan Penataan Ruang Kabupaten Serdang Bedagai. Maneggio: Jurnal Ilmiah Magister Manajemen, 3(1), 13-27. doi: 10.30596/maneggio.v3i1.4760.

Hendrajana, I. G. M. R., Sintaasih, D. K., \& Saroyeni, P. (2017). Analisis hubungan status kepegawaian, komitmen organisasional dan kinerja karyawan. EJurnal Ekonomi dan Bisnis Universitas Udayana, 6(1), 357-384. Retrieved from: https://ojs.unud.ac.id/index.php/ $\mathrm{EEB} /$ article/view/24339.

Kasmini, N. W. A., Wirama, D. G., \& Wirakusuma, M. G. (2017). Pengaruh pendidikan, kompetensi, kompensasi, motivasi, dan komitmen organisasi pada kinerja bendahara sekolah menengah di Kabupaten Gianyar. EJurnal Ekonomi dan Bisnis Universitas Udayana, 6(1), 109-136. Retrieved from: https://ojs.unud.ac.id/index.php/ EEB/article/view/24142.

Keputusan Menteri Kesehatan Republik Indonesia Nomor 900/Menkes/SK/VII/ 2002 tentang Registrasi dan Praktik Bidan. Kementerian Kesehatan Republik Indonesia.

Lasut, E. E., Lengkong, V. P. K., \& Ogi, I. W. J. (2017). Analisis perbedaan kinerja pegawai berdasarkan gender, usia dan masa kerja (Studi pada Dinas Pendidikan Sitaro). Jurnal EMBA, 5(2), 2771-2780. Retrieved from: https:// ejournal.unsrat.ac.id/index.php/emba/ar ticle/download/17155/16702.

Luthans, F., Luthans, B. C., \& Luthans, K. W. (2015). Organizational behavior: An evidence-based approach (13 $13^{\text {th }}$ edition). Information Age Publishing.

Mangkunegara, A. A. A. P. (2010). Evaluasi kinerja SDM. Refika Aditama.

Mangkuprawira, S., \& Hubeis, A. V. (2007). Manajemen mutu sumber daya manusia. PT. Ghalia Indonesia.

Maryam, S. (2014). Masa kerja, tingkat pendidikan, dan rotasi kerja meningkatkan kinerja perawat di RS jiwa dr. Soeharto Heerdjan. Jurnal Keperawatan Widya Gantari, 1(1), 3546. Retrieved from: https://ejournal. upnvj.ac.id/index.php/Gantari/article/vi ewFile/836/571.

Mukminin, A. A., Semmaila, B., \& Ramlawati, R. (2020). Effect of education and training, work discipline and organizational culture on employee performance. Point of View Research Management, 1(3), 19-28. Retrieved from: http://journal.accountingpointof view.id/index.php/POVREMA/article/v iew/33.

Mulyasari, I. (2018). Pengaruh kecerdasan emosional dan kompetensi terhadap kinerja pegawai. Journal of Management Review, 2(2), 190-197. doi: 10.25157/jmr.v2i2.1786.

Murti, H., \& Srimulyani, V. A. (2013). Pengaruh motivasi terhadap kinerja pegawai dengan variabel pemediasi kepuasaan kerja pada PDAM Kota Madiun. Jurnal Riset Manajemen dan Akuntansi, 1(1), 10-17. Retrieved from: https://www.academia.edu/10150197/P ENGARUH_MOTIVASI_TERHADA P_KINERJA_PEGAWAI_DENGAN_ VARIABEL_PEMEDIASI_KEPUASA AN_KERJA_PADA_PDAM_KOTA_ MADIUN. 
Ola, A. B., Abdullah, R., \& Azis, M. (2019). Pengaruh status kepegawaian dan komitmen organisasi terhadap kinerja melalui kepuasan kerja di UPTD Puskesmas Kajuara Kabupaten Bone. YUME: Journal of Management, 2(1), 29-42. doi: 10.2568/yum.v2i1. 359.

Paais, M., \& Pattiruhu, J. R. (2020). Effect of motivation, leadership, and organizational culture on satisfaction and employee performance. Journal of Asian Finance, Economics and Business, 7(8), 577-588. doi: 10.13106/jafeb.2020.vol7.no8.577.

Peraturan Pemerintah Nomor 46 Tahun 2011 tentang Penilaian Prestasi Kerja Pegawai Negeri Sipil. Sekretariat Negara Republik Indonesia.

Purwanto, A., Prameswari, M., Asbar, M., Ramdan, M., \& Setiawan, S. (2020). Dampak kepemimpinan, budaya organisasi dan perilaku kerja inovatif terhadap kinerja pegawai puskesmas. Jurnal Ilmu Kesehatan Masyarakat, 9(1), 19-27. doi: 10.33221/jikm.v9i01.473.

Rahmawan, A., \& Masruroh, S. (2020). Pengaruh motivasi, pengawasan dan disiplin kerja terhadap kinerja pegawai dinas pemadam kebakaran Kabupaten Pasuruan. Journal Management and Business Applied, 1(1), 35-45. Retrieved from: www.ejurnal.stieyapan. ac.id/index.php/SAMBA/article/view/9 $8 / 108$.

Ramli, A. H. (2018). Compensation, job satisfaction and employee performance in health services. Business and Entrepreneurial Review, 18(2), 177186. doi: 10.25105/ber.v18i2.5335.

Rivai, V., Ramly, M., Mutis, T., \& Arafah, W. (2012). Manajemen sumber daya manusia untuk perusahaan. PT. RajaGrafindo Persada.

Robbins, S. P., \& Judge, T. A. (2013). Organizational behavior (15 $5^{\text {th }} \mathrm{ed}$.). Pearson.
Saban, D., Basalamah, S., Gani, A., \& Rahman, Z. (2020). Impact of Islamic work ethics, competencies, compensation, work culture on job satisfaction and employee performance: The case of four star hotels. European Journal of Business and Management Research, 5(1), 1-8. doi: 10.24018/ejbmr.2020. 5.1.181.

Sendawula, K., Kimuli, S. N., Bananuka, J., \& Muganga, G. N. (2018). Training, employee engagement and employee performance: Evidence from Uganda's health sector. Cogent Business \& Management, 5(1), 1-12, doi: 10.1080/23311975.2018.1470891.

Siswanto, S., Supriyanto, A. S., I'maha, U., Asnawia, N., \& Wekke, I. S. (2019). Does a workload influence the performance of bank employees?. Management Science Letters, 9, 639650. doi: 10.5267/j.msl.2019.2.007.

Soelton, M., Pebriani, P., Umar, M., Triwulan, J., \& Wilantara, J. (2018). How transformational leadership, communication, and workload on the employee performance affect shoes industries. South East Asia Journal of Contemporary Business, Economics and Law, 17(5), 87-94. Retrieved from: http://seajbel.com/wp-content/uploads/ 2019/03/seajbel5-VOL17_241.pdf.

Sugito, Suyitno, Y., \& Kuntoro. (2019). Pengaruh masa kerja dan motivasi kerja terhadap kinerja guru sekolah dasar di Desa Samudra dan Samudra Kulon. Jurnal Dinamika Pendidikan Dasar, 11(1), 1-18. doi: 10.30595/dinamika. v11i1.5980.

Suryani, H., Pramono, J. S., Syukur, N. A., \& Mure, B. (2020). Faktor-faktor yang mempengaruhi kinerja bidan dalam pendokumentasian buku KIA. Mahakam Midwifery Journal, 5(2), 6481. Retrieved from: ejournalbidan. poltekkes-kaltim.ac.id/ojs/index.php/ midwifery/article/view/158. 
Suswati, E. (2012). Karakteristik individu dan karakteristik organisasi pengaruhnya terhadap motivasi dan kinerja bidan pada rumah sakit umum daerah tapal kuda Jawa Timur. Conference Proceeding: Capturing Opportunities for ASEAN Economic Community 2015. Universitas Kristen Satya Wacana. Retrieved from: https:// repository.uksw.edu/bitstream/1234567 89/1290/4/PROS_Endang\%20S_Karakt eristik\%20Individu\%20dan\%20Karakte ristik\%20Organisasi_Abstract.pdf.

Sutrisno, E. (2015). Manajemen sumber daya manusia. Kencana Prenadamedia Group.

von Bonsdorff, M. E., Zhou, L., Wang, M., Vanhala, S., von Bonsdorff, M. B., \& Rantanen, T. (2016). Employee age and company performance: An integrated model of aging and human resource management practices. Journal of Management, 44(8), 3124-3150. doi: $10.1177 / 0149206316662314$.
Vu, T-H., Nguyen, V-D., Ho, M-T., \& Vuong, Q-H. (2019). Determinants of Vietnamese listed firm performance: Competition, wage, CEO, firm size, age, and international trade. Journal of Risk and Financial Management, 12(2), 62-80. doi: 10.3390/jrfm12020062.

Wirawan. (2012). Evaluasi kinerja sumber daya manusia: Teori, aplikasi, dan penelitian. Salemba Empat.

Yuniarsih, T. (2013). Manajemen sumber daya manusia: Teori, aplikasi dan isu penelitian. Alfabeta.

Zulkifli \& Gani, S. (2018). Pengaruh pengawasan dan disiplin kerja terhadap kinerja pegawai pada Badan Perencanaan dan Pembangunan Daerah Provinsi Maluku Utara. Jurnal Manajemen Sinergi (JMS), 6(1), 1-17. doi: 10.33387/jms.v6i1.1303. 